\title{
EXTREME RAINFALL EVENTS AND LAKE LEVEL CHANGES IN EAST AFRICA: RECENT EVENTS AND HISTORICAL PRECEDENTS
}

\author{
DECLAN CONWAY \\ Lecturer in Natural Resources, School of Development Studies, \\ University of East Anglia, Norwich NR4 7TJ, United Kingdom
}

\section{INTRODUCTION}

Towards the end of 1961 an extreme rainfall event occurred that extended over much of East Africa stretching across the Indian Ocean to India. This event caused widespread flooding, rapid and prolonged increases in the levels of many lakes in East Africa and significant economic disruption (Odingo, 1962; Mörth, 1967). During the last few months of 1997, in a similar fashion to 1961, heavy rainfall caused flooding across East Africa (FAO/GIEW, 1998; Birkett et al., 1999). The principal driving mechanism of these extreme events has recently been established, a dipole reversal in atmospheric circulation and Indian Ocean sea surface temperatures (SSTs, Webster et al., 1999; Saji et al., 1999). Rapid progress is being made in understanding the dynamics of the event, for instance Latif et al. (1999) have directly related rainfall anomalies with Indian Ocean SSTs in ensemble general circulation model (GCM) experiments. Little is known, however, about the spatial and temporal characteristics of the hydrometeorological anomalies associated with these and other dipole events in the Indian Ocean. For instance, over India, rainfall in 1961 was the highest on record (Grove, 1996; Saji et al., 1999) but in 1997 totals were close to normal (Janowiak and Xie, 1999). Other major SST 
gradient reversals apart from 1961 and 1997 have occurred (for instance 1967 and 1994) but it is not clear to what extent other SST gradient reversals have been associated with the type of anomalies that occurred in 1961 and 1997.

This chapter provides a comprehensive assessment of the 1961 and 1997 hydrometeorological anomalies, their spatial and temporal nature, and surveys the historical records for possible precedents to the 1961 and 1997 events. The chapter is organised as follows: section 2 reviews the literature on the causes of the 1961 and 1997 events and section 3 describes the datasets used for the analysis. In section 4 the spatial and temporal characteristics of rainfall during both events are analysed and historical rainfall records are surveyed for other events with similar spatiotemporal characteristics. The impacts of the 1961 event on East African lake levels are well documented (Grove, 1996; Nicholson, 1997a, 1997b) and are reviewed briefly in section 5 along with a more detailed analysis of impacts on river flows, particularly in the Nile and Congo river basins. Section 5 also examines the causes of sustained high levels in Lake Victoria following the 1961 event, to compare with the likely duration of the impacts of the 1997 event. The implications of these events for water resource management and some conclusions are presented in section 6 .

\section{TWO EXTREME HYDROMETEOROLOGICAL ANOMALIES IN EAST AFRICA: 1961 AND1997}

\section{$2.1 \quad 1961$}

The 1961 event over East Africa was widely documented at the time (Odingo, 1962) and in subsequent analyses (Lamb, 1966; Mörth, 1967; Kite, 1981; Flohn, 1987; Grove, 1996). Odingo (1962) described the record rainfalls recorded at many sites in Kenya and the social and economic disruption caused by the event, which followed three consecutive years of low rainfall in parts of Kenya. Extensive flooding occurred in the region, loss of homes and lives, damage to crops, and emergency food had to be flown in to marooned villages. Odingo (1962) estimated the total flood damage costs at the time for Kenya to have been around five million pounds. Most studies of this event have only dealt with the characteristics of the rainfall and hydrological anomalies, although Reverdin et al. (1986) and Flohn (1987) did touch upon the climatological origins of the event. Reverdin et al. (1986) investigated the interannual variability of surface observations in the equatorial Indian Ocean between 1954 and 1976. They identified 1961, 1967 and 1963 as the three years with the largest cloudiness anomalies, synchronous with positive SST anomalies in the central Indian Ocean and negative anomalies further to the east. They describe the 1961 anomaly in detail and note that the Pacific Ocean winds were not particularly anomalous suggesting that the event was triggered by air-sea interactions in the Indian Ocean. Flohn (1987) associated the episode with a large anomaly of SST, surface winds and convective cloudiness over the western equatorial Indian Ocean. 


\section{$2.2 \quad 1997$}

During the last few months of 1997, widespread heavy rainfall caused flooding across the East and the Horn of Africa. For example, the October to February dry season in 1997-98 was the wettest on record over much of Ethiopia (Conway, 2000) and the levels of many lakes in East Africa rose significantly in response to the heavy rainfall event. The event produced wide-ranging agricultural, hydrological, ecological and economic impacts across the region summarised in Table 1.

Table 1. Summary of some of the major impacts during 1997/98 associated with the heavy rainfall event over East Africa adapted from FAO/GIEW (1998).

\begin{tabular}{|c|c|c|}
\hline Country & Agricultural impacts & Non-agricultural impacts \\
\hline Somalia & $\begin{array}{l}\text { Crop damage in secondary 'Deyr' } \\
\text { season, losses up to } 80 \% \text { in some } \\
\text { regions. Replanting after flood } \\
\text { recession. }\end{array}$ & $\begin{array}{l}\text { Estimated } 2,000 \text { deaths, } 250,000 \\
\text { displaced persons, } 35,500 \text { animals lost, } \\
\text { serious damage to housing and } \\
\text { infrastructure. Outbreak of Rift Valley } \\
\text { Fever after December } 1997 \text {. }\end{array}$ \\
\hline Kenya & $\begin{array}{l}\text { 1997/98 maize crop affected during } \\
\text { harvest. Worst effects on second-season } \\
\text { crops (mid-October to February) - yields } \\
\text { reduced by up to } 33 \% \text {. }\end{array}$ & $\begin{array}{l}\text { Serious floods caused loss of life, damage } \\
\text { to housing and infrastructure. Outbreak of } \\
\text { Rift Valley Fever after December } 1997 . \\
\text { Beneficial effect on pastures. }\end{array}$ \\
\hline Tanzania & $\begin{array}{l}\text { Localised crop losses and damage to } \\
\text { 'Vuli' crop in lowland areas, some gains } \\
\text { in yield in highland areas due to higher } \\
\text { rainfall. }\end{array}$ & $\begin{array}{l}\text { Disruption of road and rail systems. } \\
\text { Beneficial effect on pastures. }\end{array}$ \\
\hline Uganda & $\begin{array}{l}\text { Despite localised crop losses the heavy } \\
\text { rains were beneficial for crop } \\
\text { development. }\end{array}$ & $\begin{array}{l}\text { Floods and mudslides, mainly in eastern } \\
\text { areas, caused loss of life, damage to } \\
\text { housing and infrastructure. }\end{array}$ \\
\hline Ethiopia & Disrupted crop harvesting processes & $\begin{array}{l}\text { Extensive flooding in southeast areas } \\
\text { bordering Somalia and Kenya, caused loss } \\
\text { of life, damage to housing and } \\
\text { infrastructure and displacement of people. } \\
\text { Over } 12,000 \text { animals lost, } 30,000 \text { ha } \\
\text { inundated. }\end{array}$ \\
\hline Eritrea & $\begin{array}{l}\text { Spoilage of harvested crops, grain } \\
\text { output expected to be reduced. }\end{array}$ & $\begin{array}{l}\text { High levels of local locust outbreaks } \\
\text { reported. }\end{array}$ \\
\hline
\end{tabular}

The event in 1997 prompted studies into its nature and causes (Birket et al., 1999; Chambers et al., 1999; Saji et al., 1999 and Webster et al., 1999) and has renewed interest in the earlier 1961 event. Both Webster et al. (1999) and Saji et al. (1999) show the importance of the Indian Ocean circulation itself for generating these anomalies, independent of more distant phenomena such as the El Niño Southern Oscillation (ENSO). Webster et al. (1999) propose a mechanism to 
account for the 1997-98 event (and hence also earlier events) based on a characteristic internal mode of the Indian Ocean climate system. Beginning in June (July) 1997, strong, cool (warm) SST anomalies developed in the eastern (western) Indian Ocean reaching a maximum of below $-2^{\circ} \mathrm{C}$ in November (over $+2^{\circ} \mathrm{C}$, February 1998). These anomalies produced a reversal of the usual SST gradient (in absolute temperatures) and the normal westerly winds were replaced by easterly winds. The sea surface height was depressed in the east and generally higher in the west. Saji et al. (1999) define the reversal in SST gradient using the difference in SST anomaly between the tropical western Indian Ocean and the tropical southeastern Indian Ocean and refer to it as a dipole mode index (DMI). Rainfall anomalies during the event (gauge-measured and out-going longwave radiation estimates) were above average in the western and northwestern Indian Ocean and below average in the east (Sumatra and Malaysian Archipelago), associated with ascendance in the west and subsidence in the east (Webster et al. 1999).

\subsection{Disentangling the Role of ENSO}

Webster et al. (1999) suggest the changes were not an exaggerated response to the strong 1997-98 El Niño. Many of the SST and sea surface height changes can be explained by changes occurring in the surface winds. Many of the features of the 1997 event were different to those usually associated with a Pacific warm event. Correlation between mean equatorial SST in the Indian Ocean and ENSO is +0.52 but only +0.19 between ENSO and the equatorial SST gradient. The correlation between East Africa 'short rains' (October-November) and the equator Indian Ocean SST gradient is +0.62 . The circulation and SST patterns in 1997 were similar to those of other events, particularly 1961. Webster et al. (1999) identify 16 years between 1950 and 1998 in which the equatorial SST gradient (or DMI) reversed for at least one month. Only three of these were El Niño years and none La Niña.

Latif et al. (1999) use ensemble GCM experiments with prescribed SST anomalies to show that the strong rainfall anomalies in December and January 199798 (note that this does not include October or November 1997) were driven by Indian Ocean anomalies and not directly by El-Niño related SST anomalies in the equatorial Pacific. Although positive rainfall anomalies over East Africa are associated with warm ENSO extremes, Latif et al. (1999) found SST anomalies, as measured by the Niño 3 index, only accounted for 20 per cent of the December to January rainfall variability. Indian Ocean SST anomalies, particularly in the western and south western tropical Indian Ocean, account for up to 60 per cent of the rainfall variance (Latif et al. 1999). They discuss the potential for seasonal climate forecasting given that there is some predictability in Indian Ocean SSTs which respond to tropical Pacific SST fluctuations with a lag of several months. However, a significant component of Indian Ocean SST fluctuations are not related to ENSO and the 1997-98 SST anomaly pattern was not typical of the more usual SST anomalies observed during ENSO events (Venzke et al., 2000). Latif et al. (1999) cite work from Grötzner et al. (in press) which does suggest, however, that the 
December-January 1997-98 anomaly was forced remotely by SST anomalies in the Pacific.

During El Niño events, Reason et al. (2000) found more zonal easterly flow anomalies occurred over the central Indian Ocean, across generally warm SST anomalies leading to enhanced rainfall production. Using satellite altimeter and wind observations Chambers et al. (1999) related Indian Ocean warming in 1994 and 1997 with westerly wind anomalies in the central Indian Ocean connected with the ENSO. These anomalies were suggested to excite downwelling Rossby waves which move westward and depress the southwestern Indian Ocean thermocline.

Using an Ocean GCM, Murtugudde et al. (2000) studied the basic processes that caused warm and cold SST anomalies during the 1997 event. They found similarity with the evolution of other weaker Indian Ocean events suggesting that they represent a natural mode of oscillation in the Indian Ocean. They suggest this oscillation is externally forced by ENSO but also speculate that it is generated by ocean-atmosphere interactions internal to the Indian Ocean. Time series of SST anomalies for the west $\left(5^{\circ} \mathrm{S}-5^{\circ} \mathrm{N} 45^{\circ}-55^{\circ} \mathrm{E}\right)$ and east $\left(5^{\circ} \mathrm{S}-5^{\circ} \mathrm{N} 90^{\circ}-100^{\circ} \mathrm{E}\right)$ Indian Ocean show significant warm western anomalies tend to occur together with strong cool eastern events $(r=-0.44$ for $1958-97$, significant at the 10 per cent level). The eastern cooling was greater than $-1^{\circ} \mathrm{C}$ in 1961,1994 and 1997 and greater than $-0.5^{\circ}$ in many other years. Many of the stronger cooling episodes coincide with ENSO years but the correlation between zonal and meridional wind anomalies with the Southern Oscillation Index is not very large ( 0.57 and -0.51 , respectively) and many events do not occur during major ENSO events.

In conclusion, the role ENSO plays in either initiating or influencing these events in the Indian Ocean is at present unclear, particularly given that 1961 was not an El Niño year, and this is an important question for further research.

\subsection{Longer Time Scales}

There are very few high-resolution long term climate series for the region pre-dating 1900 to indicate whether similar extreme events have occurred in the past. Nicholson's (1997a and b) reconstructions of East African lake levels for the $18^{\text {th }}$ to $20^{\text {th }}$ centuries and the Nile series of annual flood maxima at Cairo back to the $7^{\text {th }}$ century are the most suitable records, although new high-resolution reconstructions are beginning to appear. Recently, Verschuren et al. (2000) have produced a 1,100 year decadal resolution rainfall and drought reconstruction inferred from Lake Naivasha in Kenya. A 194-year annual record of coral growing at Malindi, Kenya shows changes in SSTs coherent with instrumental and proxy records of tropical Pacific climate variability (Cole et al., 2000). An overall warming trend of $1.3^{\circ} \mathrm{C}$ has occurred since 1840, much of it in the recent period. The record shows strong association with a 147 year record from the Seychelles (Charles, et al. 1997). Both annual records, from November to the following October, show strong peaks around 1878, a year with an extremely high Niño 3.4 SST anomaly and high all-India rainfall. Smaller peaks occur around 1915-20, but in the early 1960s the Malindi record reaches the minimum of a 20-year cooling trend with a large cold SST 
anomaly around 1963-64, whereas the Seychelles record shows no particular patterns. Neither record extends to 1997-98. Both records show stronger coherence with Pacific Ocean SSTs than with all-India and East African rainfall indices.

\section{DATA AND METHODS}

Rainfall series from Hulme (1994, updated) and the merged satellite and station dataset from Xie and Arkin (1998) are used for the analysis. For spatial analysis of the 1961 event and others pre-1995, all stations with at least 15 years complete record between 1961 and 1990 are used to define percentage rainfall anomalies from the 1961-90 baseline for the period of interest. This extensive subset (sampling during the period with greatest station coverage in East Africa) is used to give the best possible spatial and temporal coverage. Only a few stations have temporal coverage from 1960 up to 1998 which precludes extensive direct comparison of the 1961 and 1997 events using station data alone. Therefore, the Xie and Arkin dataset (1998, for the period 1979-1999) is also used for analysis of the 1997 event. To identify other events with similar temporal characteristics, zonally averaged (calculated over $5^{\circ}$ zones from $25^{\circ}$ East to the coast) rainfall series are derived from Hulme (1994, updated) for the period 1900 to 1998 . The series are calculated as an unweighted average of all gauges with at least 15 years data between 1961 and 1990 using the mean of the percentage departures from each station's 1961-1990 mean to take the series back to 1900 as described in Jones and Conway (1997). Many of the series have very few gauges contributing during the first and last decades of this period and should be interpreted with caution. The first decade in these series is shown with dashed lines in Figures 1 and 2, the final decade is not shown but is discussed in section 4.2.

Riverflow and lake level data for the Nile are primarily from Hurst and Phillips (1933 plus supplements). The Congo, Oubangui and Tana riverflow series are from UNESCO (1995, Congo updated from Laraque et al., 1998) and the Zambezi series from Grove (1996). Table 2 lists the river and lake gauge locations and basin areas.

\section{RAINFALL: THE 1961 AND 1997 EVENTS AND HISTORICAL PRECEDENTS}

\subsection{Rainfall in 1961}

Annual and October-November $(\mathrm{ON})$ rainfall series for nine $5^{\circ}$ zonally averaged areas (from $20-15^{\circ} \mathrm{N}$ to $20-25^{\circ} \mathrm{S}$ ) are shown in Figures 1 and 2 , respectively. In the annual series 1961 stands out as extremely wet between $5^{\circ} \mathrm{N}$ and $15^{\circ} \mathrm{S}$ (the wettest year on record in three series, and second wettest in the $10-15^{\circ} \mathrm{S}$ series). Rainfall is close to average in the other zones, except $20-15^{\circ} \mathrm{N}$ where it was 
amongst the ten wettest years on record. A similar pattern is exhibited during ON for most regions, excepting $10-5^{\circ} \mathrm{N}$ (slightly more extreme) and $5-10^{\circ} \mathrm{S}$ (less extreme, third wettest on record). The ON 1961 anomaly is also very marked when September and December are included (not shown) with anomalies showing similar patterns, most pronounced at $10-5^{\circ} \mathrm{N}$ and between $5-10^{\circ} \mathrm{S}$ and $10-15^{\circ} \mathrm{S}$. Rainfall in the other seasons during 1961 (not shown) was unremarkable except in June to September (JJAS) between $5^{\circ} \mathrm{N}$ and $15^{\circ} \mathrm{S}$ where it was well above average, but not exceptional. Rainfall during January and February and the March to May (MAM) long rains in 1962 was fairly unexceptional, except at $10-15^{\circ} \mathrm{S}$, where rainfall was amongst the wettest ten years in both seasons.

Table 2. Characteristics of lake level and river flow series. 1 = Main Nile, 1871-1910 Aswan (dashed line), 1890-1939 Wadi Halfa, 1940-64 Kajnarty, 1965-90 Dongola, 2 = Blue Nile, 1900-11 Khartoum (dashed line), 1912-63 Roseires, 1964-97 El Deim, 3 = Runoff is calculated as the difference between river flow at the outlet to Lake Victoria and downstream at Mongalla, just upstream of the Sudd swamps on the White Nile. This stretch includes gains and losses through Lakes Kyoga, Edward, George and Albert and tributary inflows. $4=1961-90$ or earlier, depending upon record length. $5=1962-64$. $6=$ Per cent difference between 1961-90 and 1961-64. MAR = mean annual river flow $\left(\mathrm{m}^{3} \mathrm{~s}^{-1}\right)$.

\begin{tabular}{|c|c|c|c|c|c|c|c|c|}
\hline River / Lake & $\begin{array}{l}\text { Gauge } \\
\text { location }\end{array}$ & $\begin{array}{l}\text { Lat. } \\
\left(\mathrm{N}^{\circ}\right)\end{array}$ & $\begin{array}{l}\text { Lon. } \\
\left({ }^{\circ} \mathrm{E}\right)\end{array}$ & $\begin{array}{l}\text { Period of } \\
\text { record }\end{array}$ & $\begin{array}{c}\text { Basin } \\
\text { area } \\
\left(\mathrm{km}^{2}\right)\end{array}$ & $\begin{array}{l}\text { MAR } \\
1961- \\
1990^{4}\end{array}$ & $\begin{array}{c}\text { MAR } \\
1961- \\
1994 \\
\end{array}$ & $\begin{array}{l}\text { Per cent } \\
\text { change }^{6}\end{array}$ \\
\hline Main Nile & Dongola $^{1}$ & 19.10 & 30.32 & $1890-1990$ & - & 2745 & 3227 & +18 \\
\hline Atbara & 3 kilo & 7.41 & 34.00 & 1903-1981 & 137000 & 296 & 434 & +47 \\
\hline Blue Nile & El Deim ${ }^{2}$ & 11.23 & 34.98 & 1912-1997 & 195000 & 1458 & 1823 & +25 \\
\hline Sobat & Hillet Doleib & 9.20 & 31.38 & $1905-1979$ & 231000 & 437 & 527 & +21 \\
\hline $\begin{array}{l}\text { Equatorial } \\
\text { Lakes }^{3}\end{array}$ & $\begin{array}{l}\text { Owen Falls } \\
\text { Mongalla }\end{array}$ & $\begin{array}{l}0.43 \\
5.12\end{array}$ & $\begin{array}{l}33.23 \\
31.46\end{array}$ & $1905-1982$ & 293000 & 314 & 429 & +37 \\
\hline $\begin{array}{l}\text { Lake } \\
\text { Victoria }\end{array}$ & Owen Falls & 0.43 & 33.23 & 1896-1997 & 258000 & 1174 & $1394^{5}$ & +19 \\
\hline Tana & Garissa & $0.45^{\circ} \mathrm{S}$ & 39.70 & 1934-1975 & 42220 & 203 & 282 & +39 \\
\hline Congo & Kinshasa & $4.30^{\circ} \mathrm{S}$ & 15.30 & 1903-1994 & 3475000 & 42,091 & 50,600 & +20 \\
\hline Oubangui & Bangui & 4.37 & 18.58 & $1911-1990$ & 500000 & 3716 & 5110 & +38 \\
\hline Zambezi & $\begin{array}{l}\text { Livingstone / } \\
\text { Victoria Falls }\end{array}$ & $17.95^{\circ} \mathrm{S}$ & 25.90 & $\begin{array}{c}1907 / 8- \\
1993 / 4 \\
\end{array}$ & 360683 & 1172 & 1586 & +35 \\
\hline
\end{tabular}

Maps of percentage rainfall anomalies in 1961 for MAM, JJAS, ON and annual periods are shown in Figure 3. The 1961 event covered an area stretching from southern Sudan and the Eritrean coast in the North to northern Zambia and Zimbabwe in the South (no data for Mozambique). The event was centred over eastern Uganda, southern Kenya and northern Tanzania, peaked in November 1961 and ranged in magnitude from slightly dry conditions over southeast Sudan to 200 per cent increases in annual rainfall over Kenya, Eritrea and Somalia in 1961. Seasonal anomalies were greatest in ON 1961, ranging up to 400 per cent over Lake Turkana (southwest Ethiopia) and the East African coast. The ON anomaly covered Uganda, Kenya, and northern Tanzania up to central Ethiopia and across Somalia. 
Dry conditions occurred over Sudan and near normal conditions south of $15^{\circ} \mathrm{S}$. High annual rainfall totals in 1961 extend to $20^{\circ} \mathrm{S}$ due to high rainfall during JJAS over large parts of the region and particularly over Malawi and Zimbabwe. Whether this earlier heavy rainfall was a southerly precursor of the ON event or unconnected with it is not clear. Figure 4 shows the time series of mean (1961-1990) and monthly rainfall 1960-1965 averaged over the $5^{\circ}$ zones. High rainfall was experienced during the JJAS season over $20-15^{\circ} \mathrm{N}$ and $15-10^{\circ} \mathrm{N}$ with near normal conditions after September. It is only the regions which generally experience substantial rainfall during the short rains period $(\mathrm{ON})$ between $10^{\circ} \mathrm{N}$ and $10^{\circ} \mathrm{S}$ that record large monthly anomalies. There is some indication of a southwards transgression in high rainfall following the movement of the ITCZ; from August at $5-0^{\circ} \mathrm{N}$, peaking in November over $5^{\circ} \mathrm{N}$ to $5^{\circ} \mathrm{S}$, in December over $5^{\circ} \mathrm{S}$ to $15^{\circ} \mathrm{S}$ where it also continued into January (contributing to high annual rainfall for 1962 over $10^{\circ}-15^{\circ} \mathrm{S}$ ) but dissipating south of $15^{\circ} \mathrm{S}$.

\subsection{Rainfall in 1997}

For 1997 the zonal average series have only between two and 11 stations with data and the $20-15^{\circ} \mathrm{N}$ and $0-5^{\circ} \mathrm{S}$ series have no data, which restricts analysis of the event and extensive comparison with 1961. Most of the series become rather erratic after 1990 due to the low numbers of stations with data and are therefore not shown in Figures 1 and 2 after this date. The series, however, do show the following for 1997. The anomaly is most pronounced between $10^{\circ} \mathrm{N}$ and $10^{\circ} \mathrm{S}$, particularly at 0 $5^{\circ} \mathrm{S}$ (wettest year on record, although note that only two stations contribute to the series in this year), and $10-5^{\circ} \mathrm{N}$ (third wettest on record and higher than 1961). Rainfall during 1997 was also well above normal from $10^{\circ} \mathrm{S}$ to $25^{\circ} \mathrm{S}$, more so than in 1961 (except for $10-15^{\circ} \mathrm{S}$ ). The anomalies during ON are more apparent than in the annual series, particularly at $15-10^{\circ} \mathrm{N}$ to $10-5^{\circ} \mathrm{N}$ and $20-25^{\circ} \mathrm{S}$. Rainfall was close to normal between $5-10^{\circ} \mathrm{S}$ and $15-20^{\circ} \mathrm{S}$.

For the period September to December the anomalies are less extreme at $15-10^{\circ} \mathrm{N}$ and $0-5^{\circ} \mathrm{S}$ and $20-25^{\circ} \mathrm{S}$, more extreme at $5-10^{\circ} \mathrm{S}$ and similar across the other zones with data. Figure 5 shows percentage rainfall anomalies for stations with data in 1997 (mainly in Ethiopia, Zambia and Zimbabwe). The highest anomalies occurred during JJAS over Zambia and during ON over Ethiopia and at Dar es Salaam in Tanzania. Figure 1 shows there is reasonable agreement between the station only and the merged satellite and station zonal time series in terms of mean rainfall amounts and temporal variability at $20-15^{\circ} \mathrm{N}, 15-10^{\circ} \mathrm{N}, 5-10^{\circ} \mathrm{S}, 10-15^{\circ} \mathrm{S}$ and $20-25^{\circ} \mathrm{S}$. For the four other zones there are marked differences between the station series and the merged series, particularly in rainfall amounts. In the merged annual data 1997 is only exceptional over $5-0^{\circ} \mathrm{N}$ and $0-5^{\circ} \mathrm{S}$ and, to a lesser extent, $5-10^{\circ} \mathrm{S}$ (6th wettest year in 21 years). 
Extreme Rainfall Events and Lake Level Changes in East Africa 70

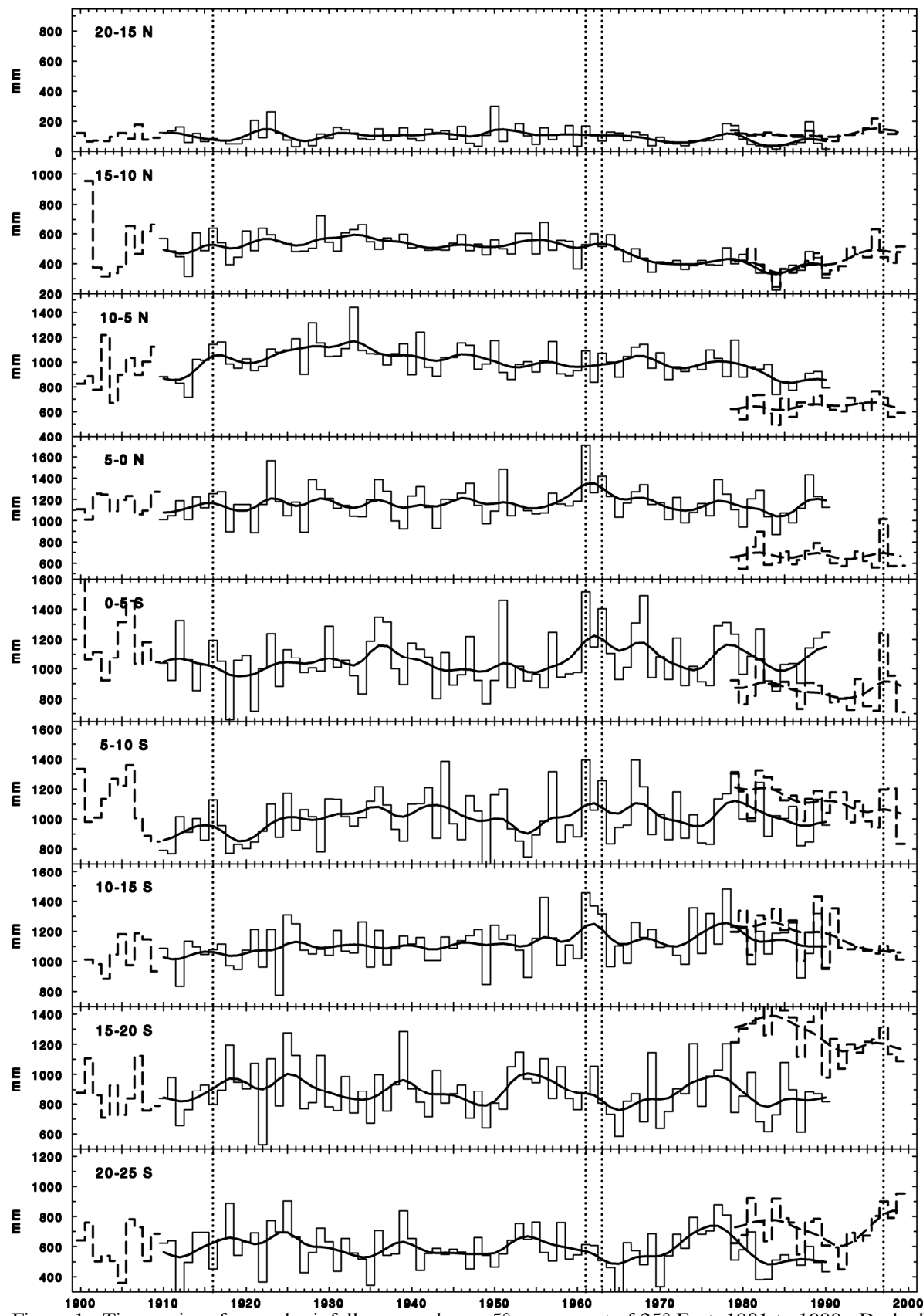

Figure 1. Time series of annual rainfall averaged over $5^{\circ}$ zones, east of $25^{\circ}$ East, 1901 to 1999 . Dashed line from 1901 to 1909 represents period with very limited data availability. Data from 1901 to 1990 are from Hulme (1994) with a 10-year gausian fitter. Dashed line from 1979 to 1999 is from Xie and Arkin (1998), with 10 year gausian fitter. Dotted vertical lines highlight four years, 1916, 1961, 1964 and 1997. 


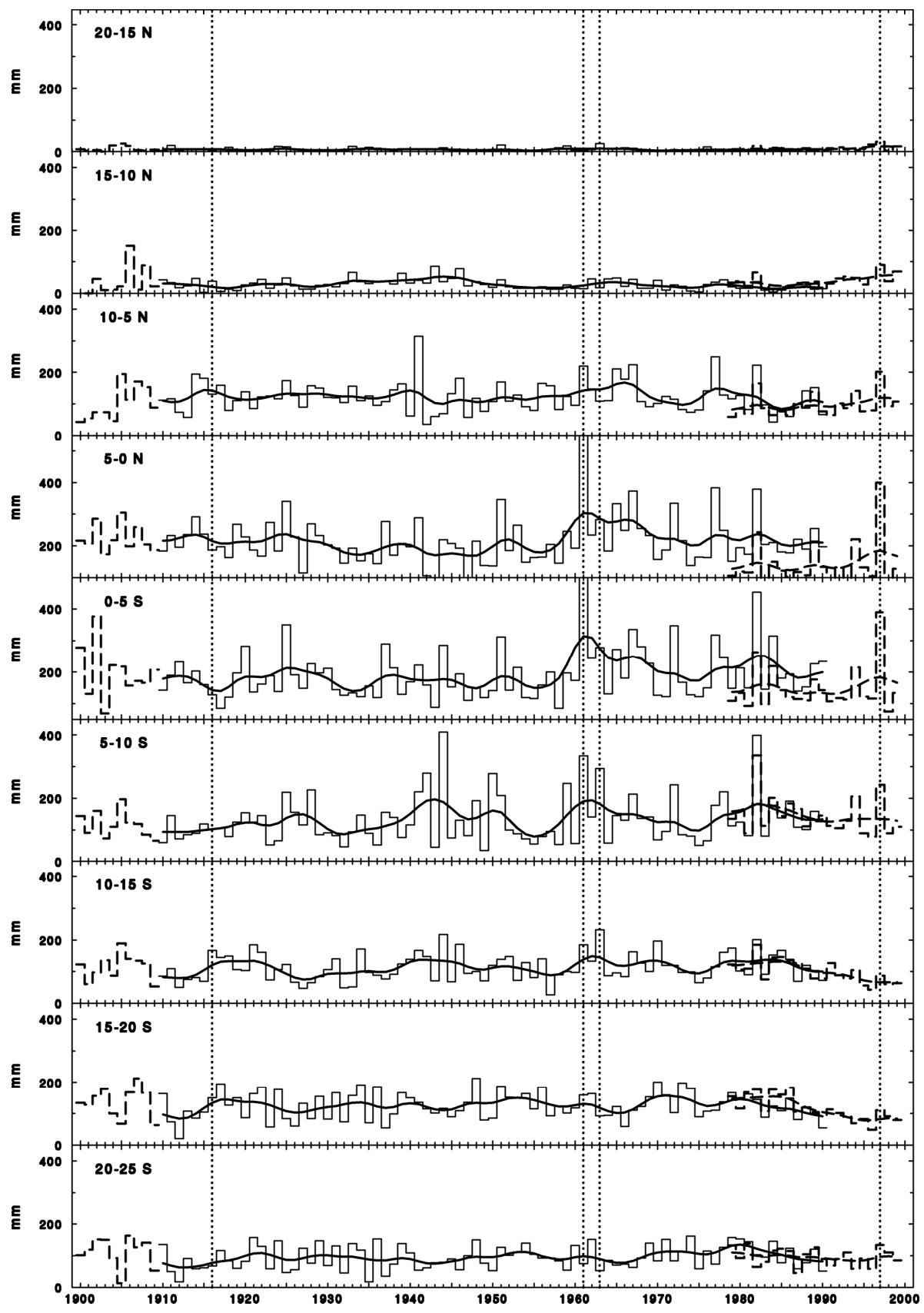

Figure 2. Time series of October - November rainfall averaged over $5^{\circ}$ zones, east of $25^{\circ}$ East, 1901 to 1999. See caption to Figure 1. 
Extreme Rainfall Events and Lake Level Changes in East Africa 72
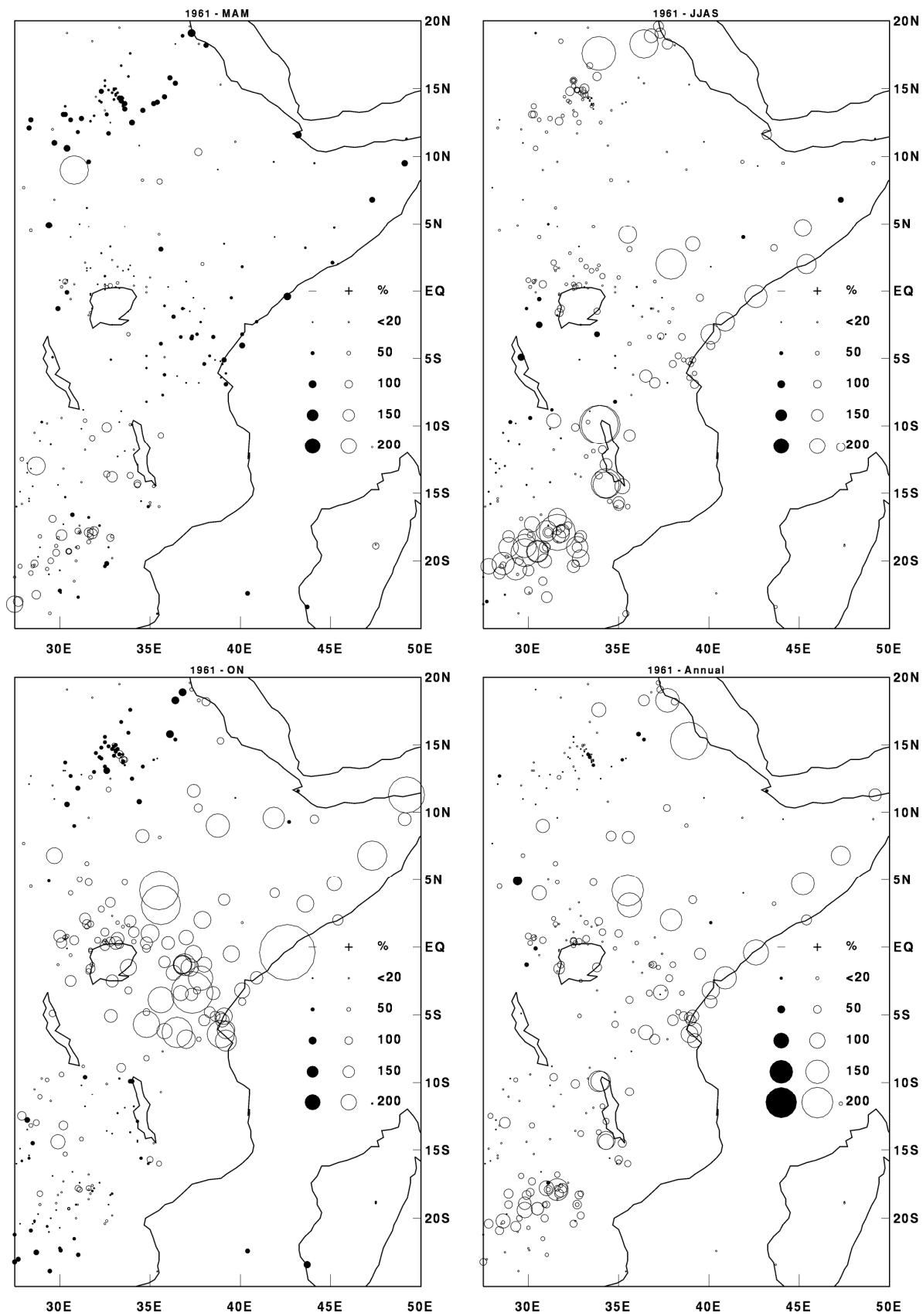

Figure 3. Rainfall anomalies in 1961 expressed as percentage departure from 1961-1990 mean for stations with available data. MAM $=$ March to May, JJAS $=$ June to September, ON $=$ October to November. 


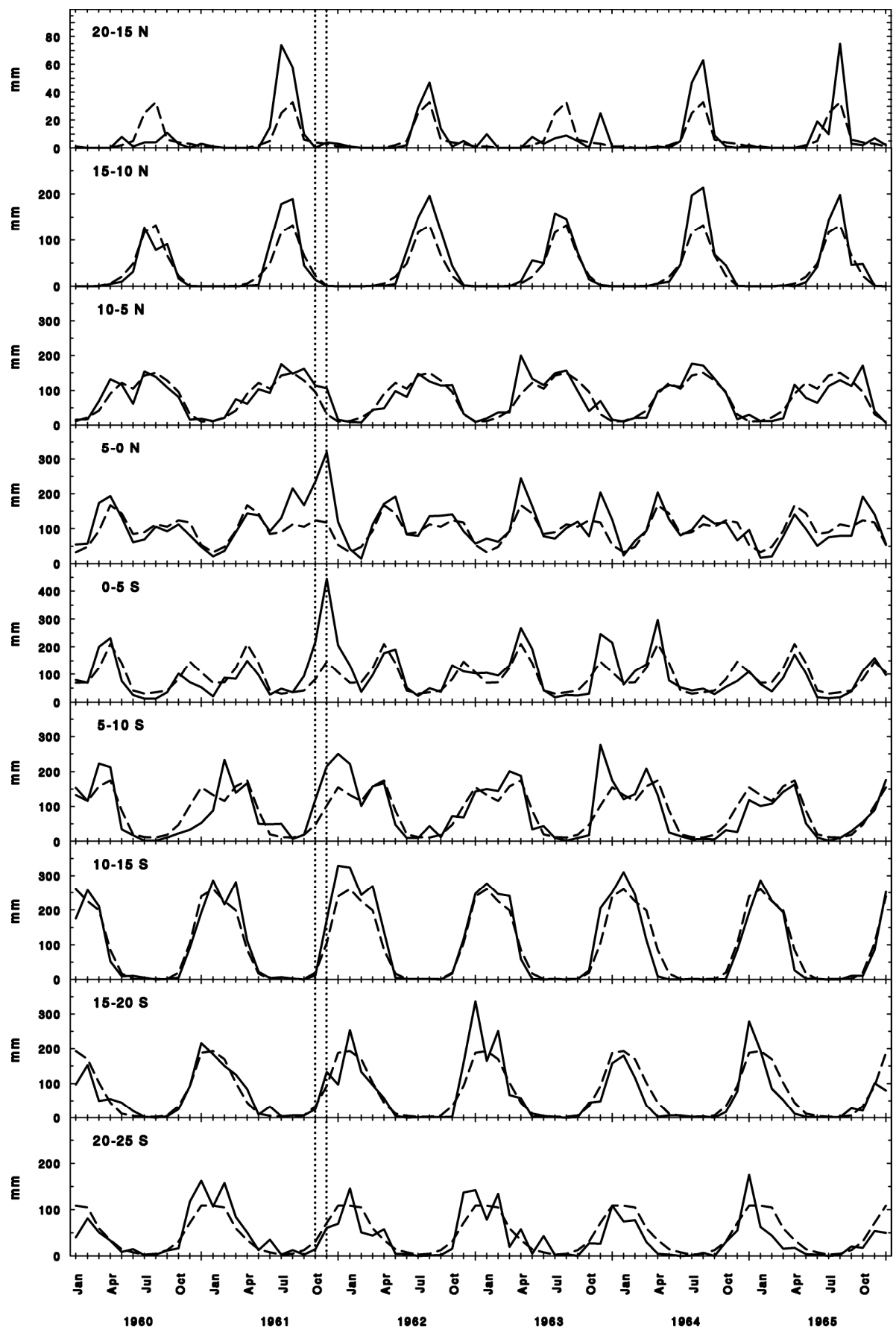

Figure 4. Time series of mean (1961-1990) and monthly (1960-1965) rainfall averaged over $5^{\circ}$ zones. Note different scales. Dotted vertical lines highlight October and November, 1961. 
Agreement between the two data sets is better for ON (Figure 2) in terms of rainfall amount and variability with large errors occurring in magnitude but not variability, over $5-0^{\circ} \mathrm{N}$ and $0-5^{\circ} \mathrm{S}$. The event is more apparent over $5-15^{\circ} \mathrm{N}$ and 5 $10^{\circ} \mathrm{S}$. Per cent monthly anomalies from the 21 -year mean in Figure 6 show the anomaly actually extends further north but is obscured in the annual totals because of the low rainfall normally recorded during this period north of $15^{\circ} \mathrm{N}$. The event is also apparent further south over $5-10^{\circ} \mathrm{S}$. The event is contemporaneous across the region beginning in October and lasting through until February 1998, except 20$15^{\circ} \mathrm{N}$ where the event disappears after November 1997.

\subsection{Historical Precedents}

ON rainfall totals shown in Figure 2 highlight other years with extreme anomalies contemporaneous across much of the region. Notable anomalies occur in $1925\left(15^{\circ} \mathrm{N}-10^{\circ} \mathrm{S}\right), 1944$ (restricted to $\left.0^{\circ} \mathrm{S}-15^{\circ} \mathrm{S}\right), 1951\left(5^{\circ} \mathrm{N}-10^{\circ} \mathrm{S}\right), 1963\left(10^{\circ} \mathrm{N}-\right.$ $\left.15^{\circ} \mathrm{S}\right), 1967\left(10^{\circ} \mathrm{N}-10^{\circ} \mathrm{S}\right), 1977\left(10^{\circ} \mathrm{N}-10^{\circ} \mathrm{S}\right), 1982\left(10^{\circ} \mathrm{N}-15^{\circ} \mathrm{S}\right.$ and $15^{\circ} \mathrm{N}-15^{\circ} \mathrm{S}$ in the Xie and Arkin data), and 1994 (restricted to $10^{\circ} \mathrm{N}-5^{\circ} \mathrm{S}, 10^{\circ} \mathrm{N}-10^{\circ} \mathrm{S} \mathrm{S}$ in the Xie and Arkin data). Only ON in 1963 and 1982 come close to matching the spatial extent and magnitude of the 1961 event. Time series for other seasons (January to February, MAM and JJAS, not shown here) do not show particularly unusual rainfall during any of these years.

Seasonal and annual anomalies are shown for 1982, which is the closest year to ON 1961, in Figure 7. Rainfall during ON was very high over Kenya and Tanzania and the Horn (over 400 per cent above average in places) and generally above average across the whole region. In the other seasons rainfall was less extreme, and generally below normal. The ON spatial pattern is similar to 1961 between $10^{\circ} \mathrm{N}-15^{\circ} \mathrm{S}$ but with wet conditions extending to $20^{\circ} \mathrm{N}$ (1961 restricted to $10^{\circ} \mathrm{N}-15^{\circ} \mathrm{S}$ ). Figure 8 shows the percentage rainfall anomalies in other years with very wet ON; 1925, 1963, 1967, and 1977. All four years show reduced rainfall south of about $15^{\circ} \mathrm{S}$ and wet to extremely wet conditions north of this point. Some particularly large anomalies occurred over southern Sudan in 1925, where normal ON rainfall is extremely low. ON 1967 was wet across the region but with most stations recording anomalies of around 100-150 per cent, except for very wet conditions for two gauges near Lake Malawi and most gauges in Ethiopia. 

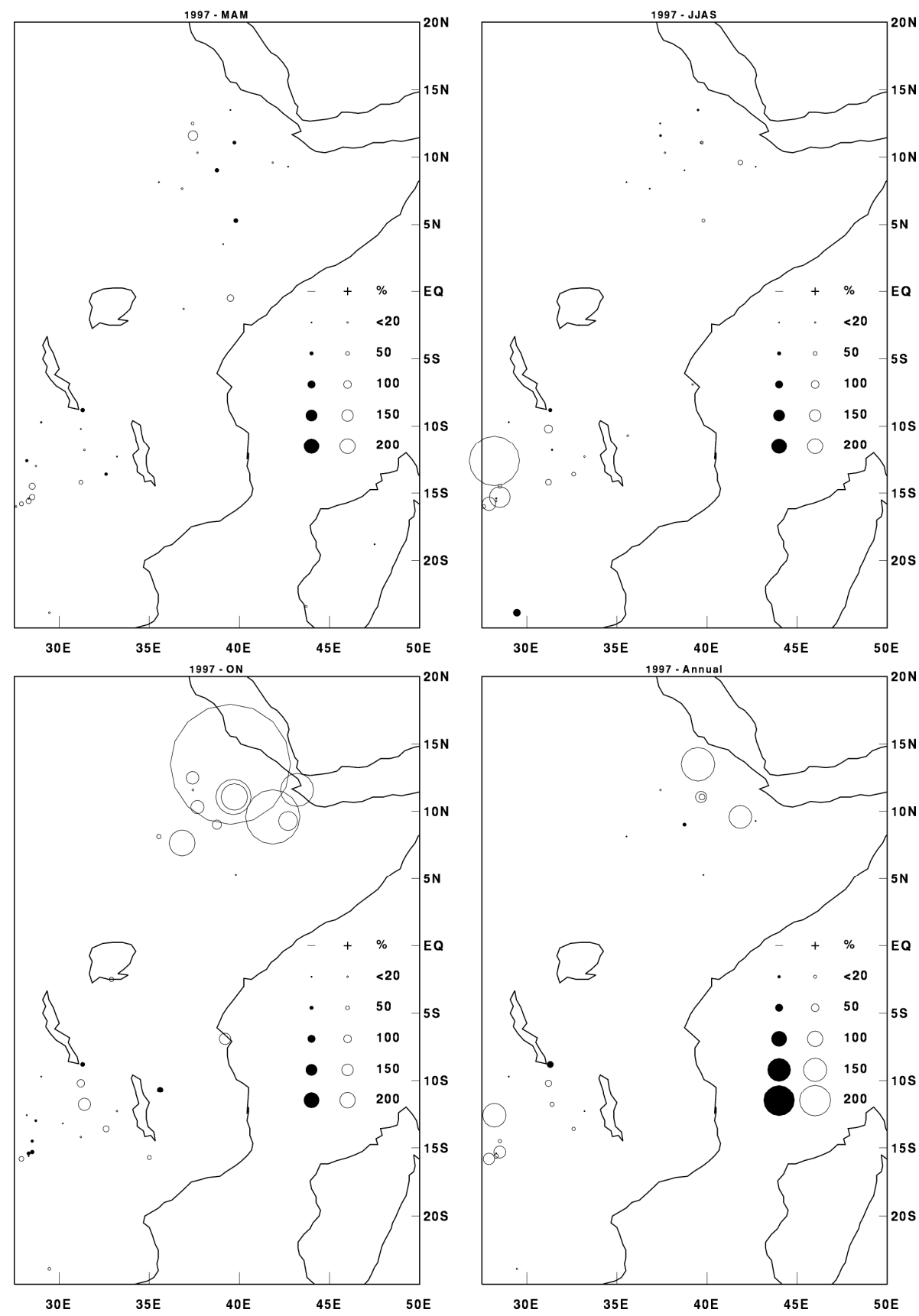

Figure 5. Rainfall anomalies in 1997 expressed as percentage departure from 1961-1990 mean for stations with available data. MAM $=$ March to May, JJAS $=$ June to September, ON $=$ October to November. 


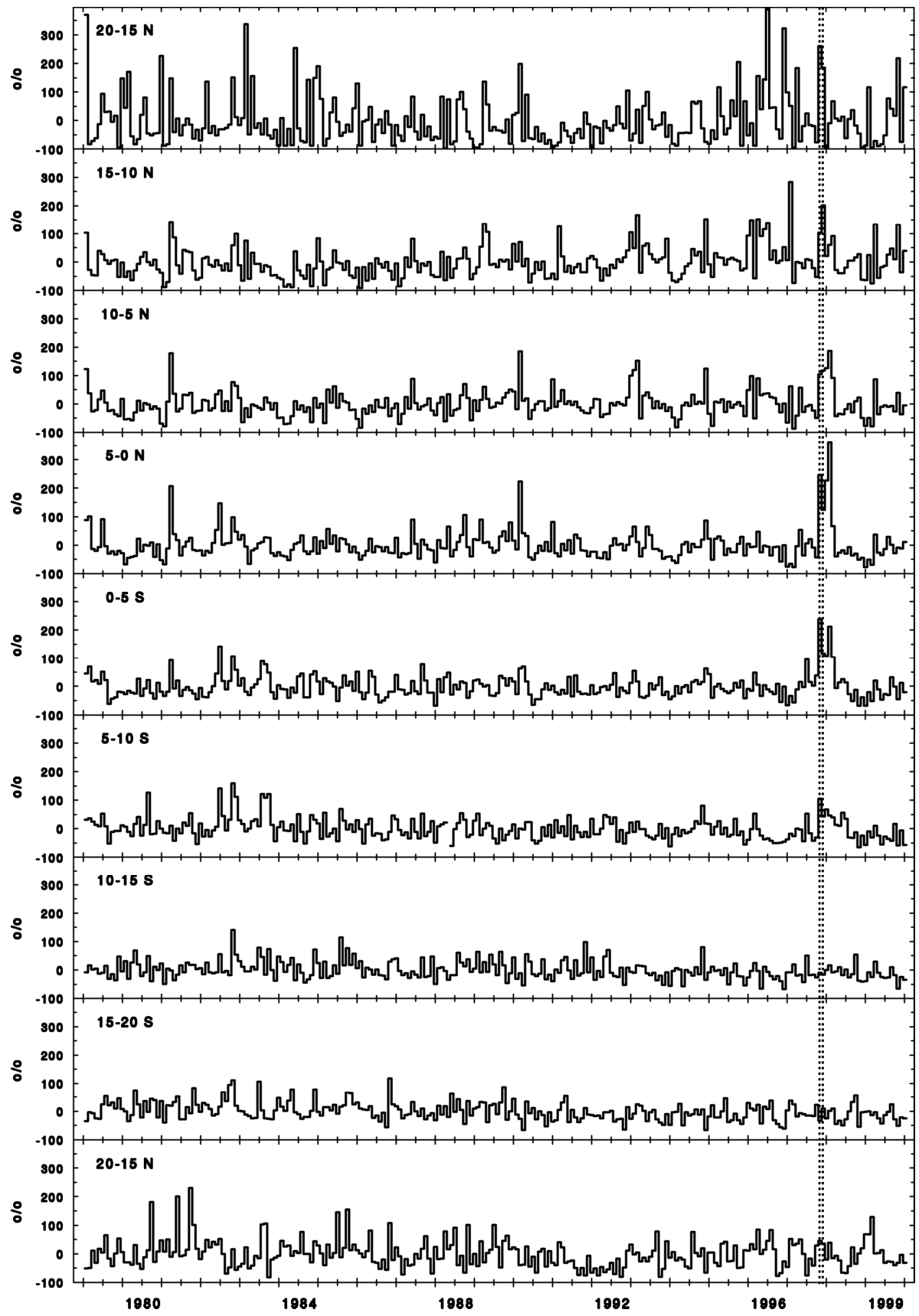

Figure 6. Time series of monthly rainfall percentage anomalies (from 1979-1999, 21 year mean) averaged over $5^{\circ}$ zones, data from Xie and Arkin (1998). Dotted vertical lines highlight October and November, 1997. 

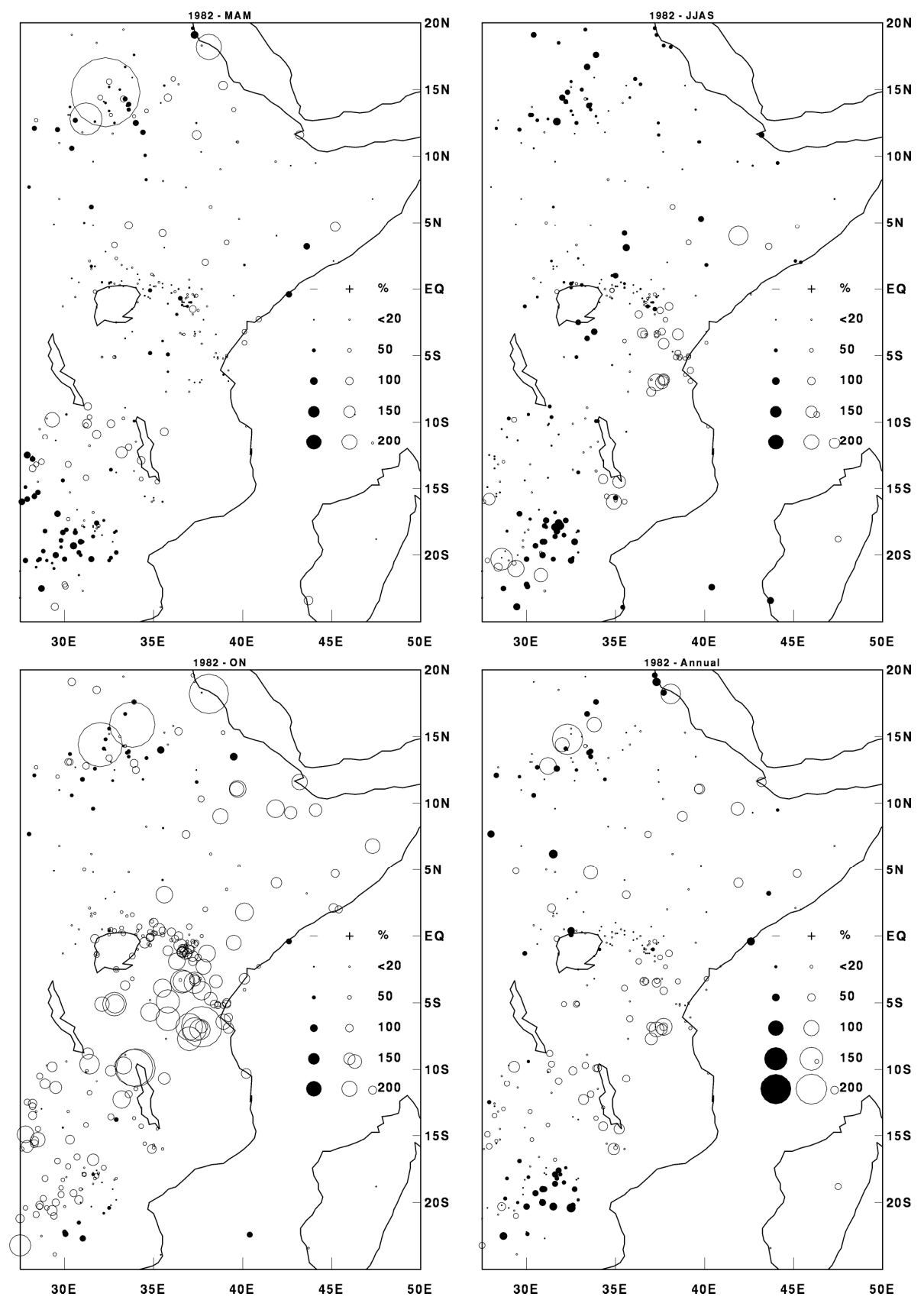

Figure 7. Rainfall anomalies in 1982 expressed as percentage departure from 1961-1990 mean for stations with available data. MAM $=$ March to May, JJAS $=$ June to September, ON $=$ October to November. 
Extreme Rainfall Events and Lake Level Changes in East Africa 78
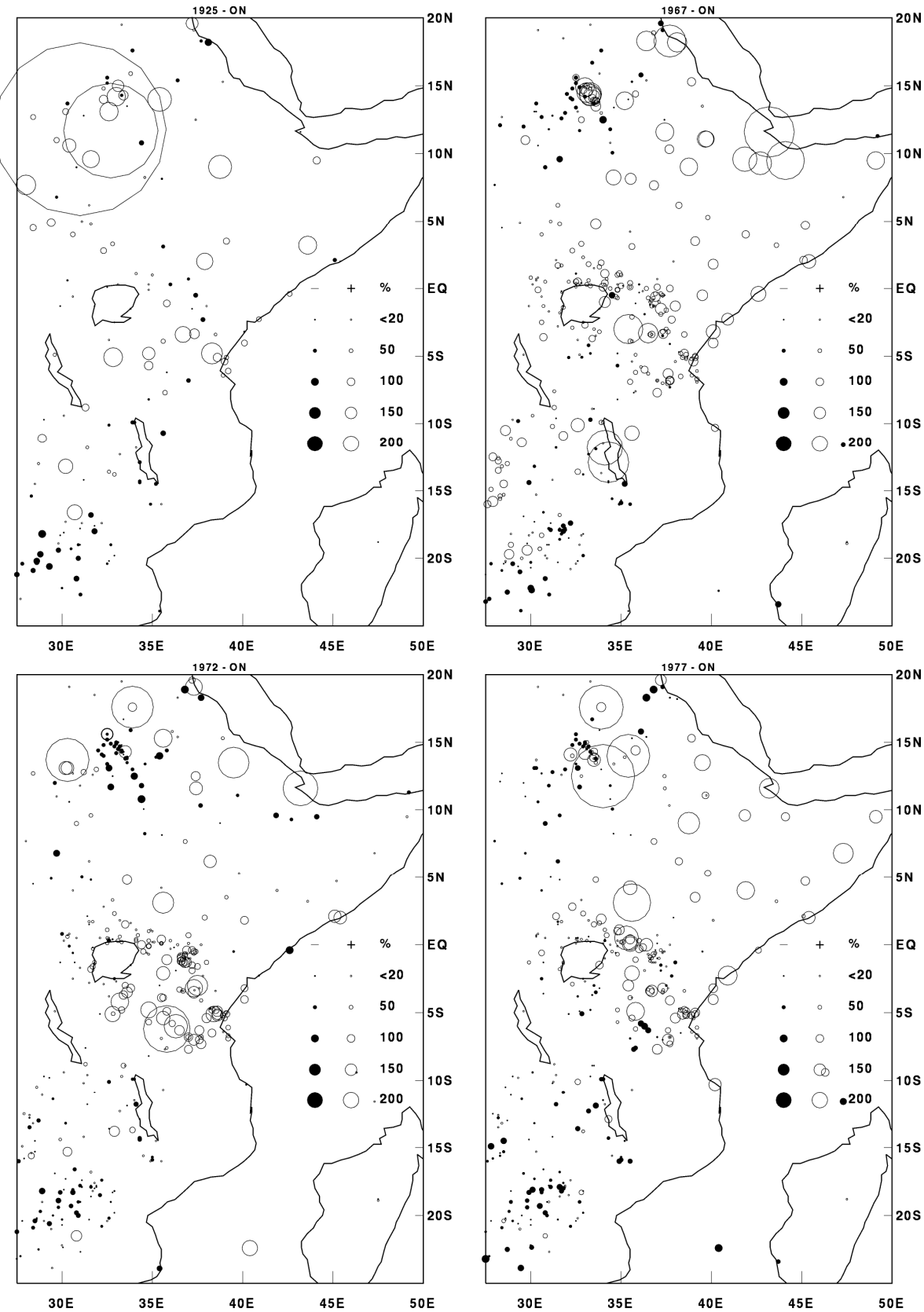

Figure 8. ON rainfall anomalies in 1941, 1973, 1967 and 1977, expressed as percentage departure from 1961-1990 mean for stations with available data. MAM = March to May, JJAS = June to September, $\mathrm{ON}=$ October to November. 


\section{HYDROLOGY: THE 1961 AND 1997 EVENTS AND HISTORICAL PRECEDENTS}

This section analyses river flow records for areas to the north, west and south of the East African lakes for which the impacts of the 1961 event are well documented (Grove, 1996; Nicholson, 1997a and b for 1961, see also Birkett et al., 1999 for 1997 impacts, and Sutcliffe and Parks, 1999 for a review of river flows in the Nile Basin). Annual river flow series are shown in Figure 9 and monthly mean (1960-90) and monthly flows (1960-65) are shown in Figure 10.

\subsection{River Flow and Lake Level Series}

\subsubsection{Main Nile}

The period of extremely high flows prior to 1899 has been the subject of a number of studies especially concerning the accuracy of the early gauge data. Of note during this high period are the floods of 1878 and 1879. Flohn and Burkhardt (1985) used correlation between dry season flows at Aswan and end of year Lake Victoria lake levels to reconstruct lake levels back to the beginning of the Aswan record, 1870, which suggested very high levels during 1878 .

Sutcliffe and Parks (1999) identified periods of high flows at Aswan (January to May, indicative of high Lake Victoria levels) during 1879, 1895-97, 1917-1918 and similar increases upstream at Dongola after 1961.

\subsubsection{Atbara and Blue Nile}

Both records show high flows during 1903-05 and 1916-17, unexceptional flows from 1961-64 in the Atbara and high Blue Nile flows in 1961 due to monsoon rainfall during JAS. Neither river records unusual flows during ON 1961. Some stage readings do exist for the Blue Nile at Khartoum prior to 1900 , for the years between 1869 and 1883 (Walsh et al., 1994). These indicate floods were more frequent and severe in the period $1869-1883$ than at any time during the $20^{\text {th }}$ Century, with 1878 producing the highest flood level on record.

\subsubsection{Sobat}

The Sobat catchment lies between roughly $5^{\circ} \mathrm{N}$ and $10^{\circ} \mathrm{N}$ where annual rainfall was not particularly high during 1961 but ON rainfall was amongst the five highest on record. The Sobat displays similar flood years to the Blue Nile, in 190405 and 1917-18 and 1962 (one year later than Blue Nile floods). Riverflows were above average during 1962 due to very high flows between December 1961 and March 1962 (Figure 10). Monthly flows were high throughout 1962 and October 1964 to February 1965. During years of heavy rainfall flooding may occur from the Sobat's tributaries draining Ethiopia feeding into the Machar marshes and other wetlands in southeast Sudan. Delayed response at the Sobat mouth may result from 
contributions from the upper Pibor which lies near Lake Kyoga (Sutcliffe and Parks, 1999) and small headwater wetlands in the upper Baro in the Ethiopian highlands (Dixon, 2000).

\subsubsection{Equatorial Lakes}

Runoff from the Equatorial Lakes catchment along the Nile region north of Lake Victoria and south of the Sudd swamps was extremely high in 1916-18. The monthly series shows a massive increase in flows occurred from August 1961, three months earlier than Lake Victoria (see below), and produced high annual runoff in 1961, whereas the increase in annual runoff from Lake Victoria only becomes notable by 1962 (Figure 9). The return in runoff rates to magnitudes typical of the pre-1961 event was faster than in Lake Victoria. Downstream impacts of high river flows along the White Nile were significant. For instance, the Sudd swamps, where from 1950-52 to 1980 the area of permanent swamp increased from $2800 \mathrm{~km}^{2}$ to $16600 \mathrm{~km}^{2}$ and the area of seasonal swamp increased from $11200 \mathrm{~km}^{2}$ to $14000 \mathrm{~km}^{2}$ (Sutcliffe and Parks, 1987).

\subsubsection{Lake Victoria}

Lake Victoria levels had two short-lived high periods during 1903-07 and 1916-18 but the annual series is dominated by the sudden change from 1962 onwards (Figure 9).

A significant and sustained increase in Lake Victoria levels and outflows occurred in late 1961 and has been fully documented in Kite (1981) and Piper et al. (1986). Lake Victoria levels peaked in 1964 and decreased steadily except for increases in 1978-79 and 1990-91 but even by 1997 they remained well above their pre-1961 levels.

\subsubsection{Tana}

The Tana river has the smallest gauged catchment area of the rivers examined here and provides the clearest and most short-lived example of riverflow response to the 1961 event. The anomaly lasts from October to December, peaking in November and generating the second highest annual flow on record. River flows in 1963 and 1964 were also high. 


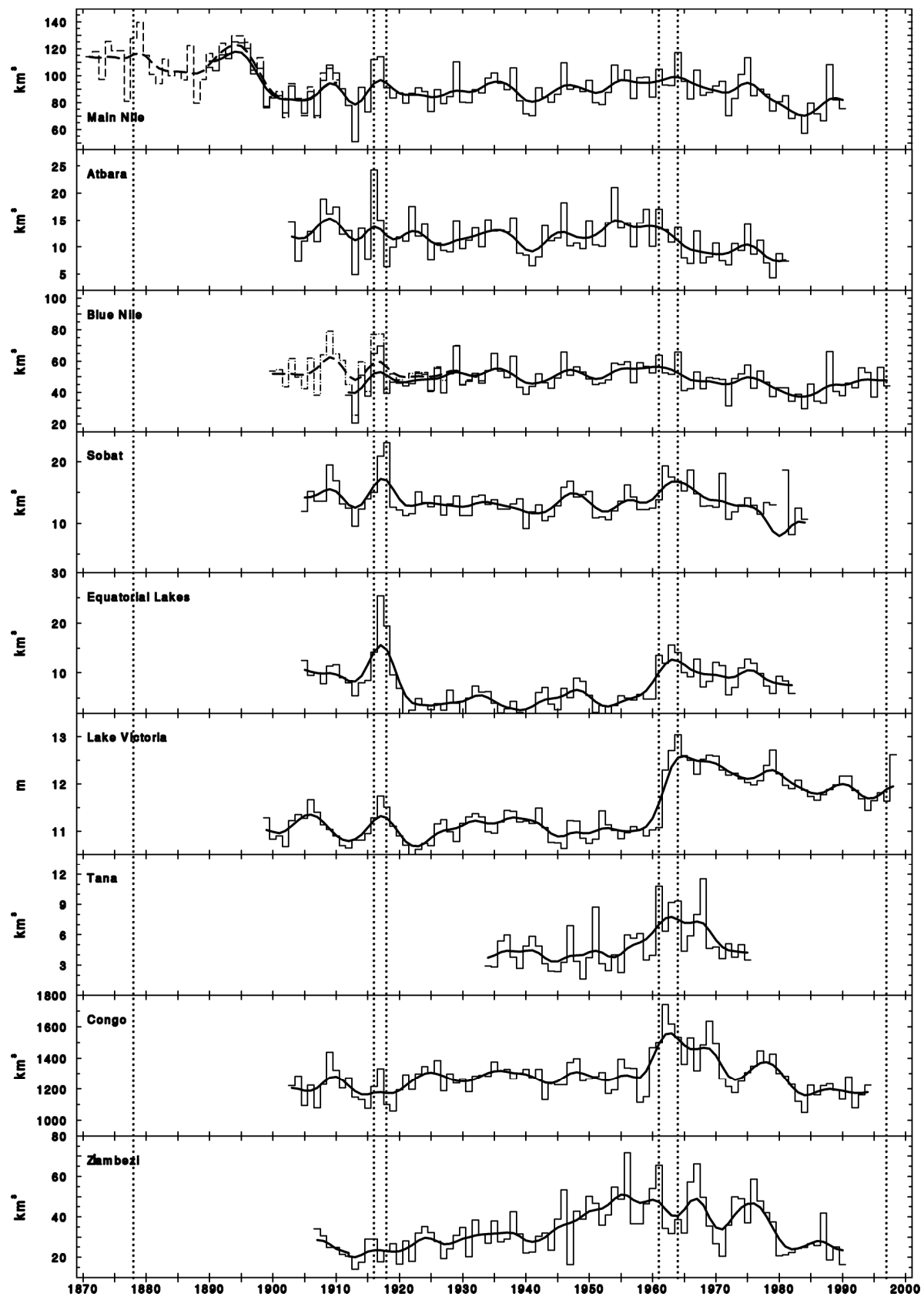

Figure 9. Time series of annual riverflows for various periods. Note different scales. Dotted vertical lines highlight five years, 1878, 1916, 1961, 1964 and 1997. See Table 2 for description of series. 
Extreme Rainfall Events and Lake Level Changes in East Africa 82

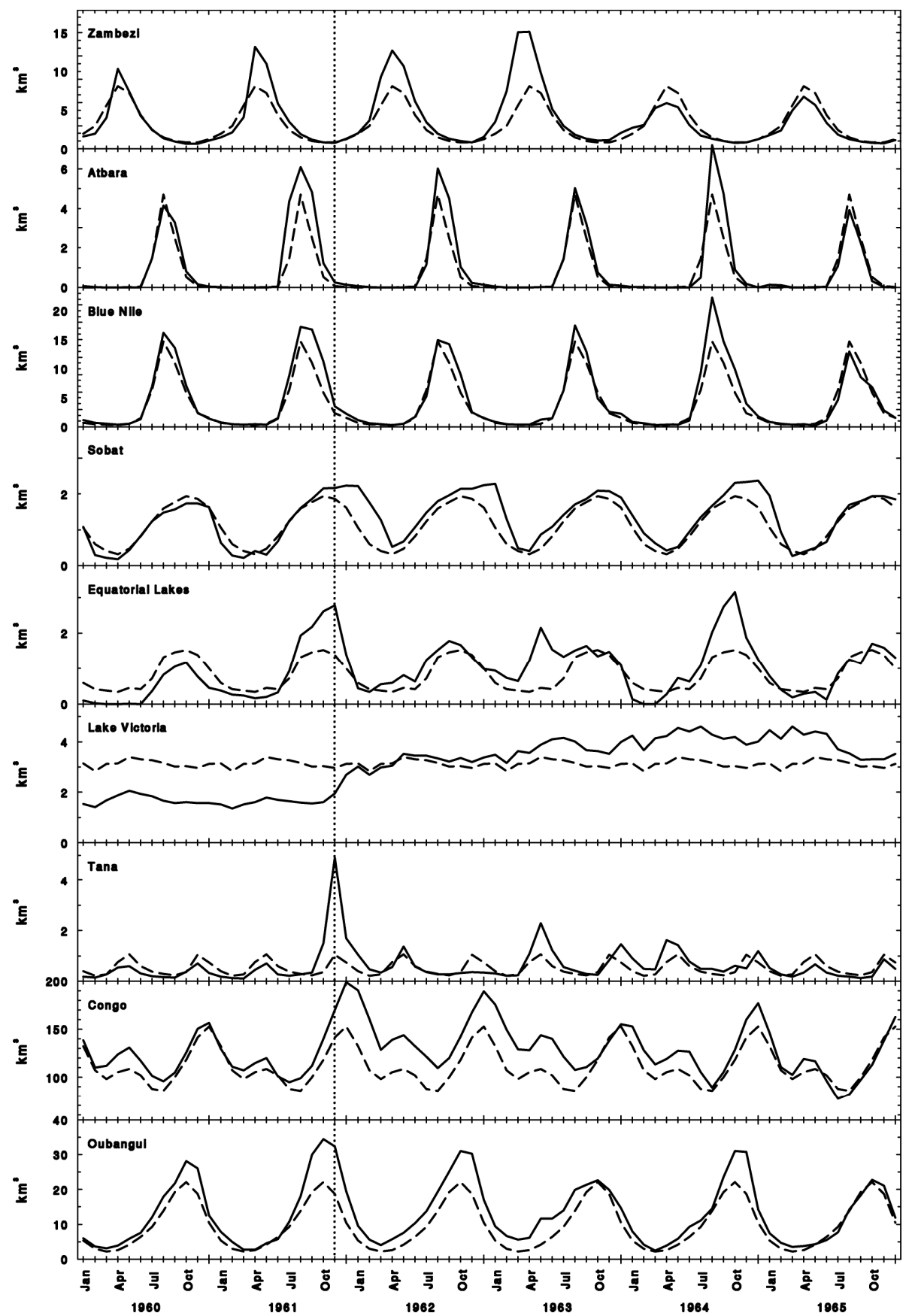

Figure 10. Time series of mean (1961-1990) and monthly (1960-1965) riverflow. Note different scales and different rivers compared to Figure 9. Dotted vertical line highlights November 1961. See Table 2 for description of series. 


\subsubsection{Congo and Oubangui}

Small floods occurred in 1909 and, as in the White and Blue Niles, 1917. October, November and December 1961 produced the highest monthly river flows on record in the Congo basin making 1961 the sixth highest annual flow on record. 1962 recorded record monthly flows from January to October and produced an even higher annual flow (over 30 per cent higher than the long-term mean). River flows remained exceptionally high until the end of 1964 , probably maintained by a combination of the following: high rainfall in 1962-64; storage within this vast complex river system with areas of seasonal and permanent wetland; and possibly additional inputs from Lake Tanganyika via the river Lukuga outlet as occurred in 1878 (section 5.3). Annual river flow in the Oubangui, a major tributary of the Congo river, is very similar (annual flows not shown) except that the significant anomalies begin one month earlier (September 1961, Figure 10). Oubangui river flows remained exceptionally high until November 1964.

\subsubsection{Zambezi}

Further to the south in the Zambezi basin river flows show quite different temporal variability to the other series. 1916-18 are unexceptional years and the prolonged increase in flows from 1940 to 1956 does not feature in any of the other series. 1961 was the third highest flood on record but was followed by three very dry years. Nicholson (1999) also notes differences in behaviour of the southerly lakes Malawi and Rukwa compared to lake level changes in the more northerly East African lakes.

\subsection{Impacts of the 1997 Event}

Hydrological data are only available for the Blue Nile and Lake Victoria in 1997. Blue Nile flows were unexceptional in 1997, much lower than in 1961, but rainfall over the catchment during the following dry season (October to February) was the highest on record (Conway, 2000). A significant rise in Lake Victoria level occurred in 1998, a rise of approximately $1.0 \mathrm{~m}$, slightly less than the $1.2 \mathrm{~m}$ rise from 1961 to 1962 (mean annual levels) which was the largest annual increase on record. Whether levels remain high as after 1961, or will fall more rapidly as after the rises in 1903-07 and 1916-18 will largely depend upon subsequent rainfall over the lake basin. Figure 1 suggests that unlike after 1961 which was followed by a sequence of wet years, rainfall during 1998 and 1999 has not been particularly high over the main contributing zone $5^{\circ} \mathrm{N}-5^{\circ} \mathrm{S}$. Satellite altimetry data also show similar Lake Victoria level increases to the observations during 1997 and 1998 (a rise of $~ 1.7 \mathrm{~m}$ by 1998, Birkett et al., 1999) but were unavailable after November 1998. Birkett et al. (1999) also identified large increases in other lake levels across East Africa as a result of the heavy rainfall, for instance Lake Tanganyika rose by $\sim 2.1 \mathrm{~m}$ and Lake Malawi by $1.8 \mathrm{~m}$ and a rise in the levels of the Sudd swamps. IRD (1999) also showed very high river flows for the Congo at Kinshasa during December 1997-March 1998, and 
during January-March 1998 when they were almost as high as during the same months in 1961-62.

\subsection{Historical Precedents}

Apart from the extreme floods in 1916-18 there are no other twentieth century events similar to the wide-ranging and extreme characteristics of the 1961-64 period. There is not enough evidence here to compare in detail the extent of the 1997 event with 1961 in terms of extreme floods and prolonged impacts on lake levels. The 1916-18 episode was smaller in magnitude and extent, mainly limited to the area of Lake Victoria, southern Sudan and southwestern Ethiopia and marked by 10 per cent to 40 per cent increases in rainfall between October 1916 and September 1917 (Conway, 1997). The largest seasonal increases (up to 100 per cent) occurred from December 1916 to February 1917. The most likely contender is 1878 which was a year of record floods on the Blue Nile, very high Lake Victoria levels and is generally noted as an extremely wet year across the region. Nicholson (1999), for example, cites the explorer Thompson as reporting Lake Tanganyika's maximum level was in 1878. Lake Tanganyika has an intermittent outlet dependent on lake level into the Lukuga river which discharges into the Congo. From documentary evidence Nicholson (1999) notes that 1878 was a year of very heavy rains which opened the Lukuga outlet which reportedly led to flooding in the Congo river. Lyons (1906) reports travellers' observations of high rainfall and lake levels in both MAM and ON seasons in 1877 and that the 'lake rose three feet $[0.91 \mathrm{~m}]$ above its usual June maximum in August and September, 1878, in consequence of the heavy rains' (p.35). Lyons makes no mention of the ON rains in 1878. It is noteworthy that 1878 was also the year of a major ENSO event.

\subsection{The Persistence of High Lake Victoria Levels After 1961}

Lake Victoria is unusual amongst the lakes in East Africa for the prolonged duration of high lake levels following 1961. Water balance studies of Lake Victoria have shown that the increase in lake levels was largely due to extremely high rainfall over the lake and catchment in ON 1961 followed by three further wet years in 1962, 1963 and 1964. Piper et al. (1986) found it was not possible, however, to account fully for the rise in lake levels using a water balance approach because their estimate of lake rainfall, which was calculated from an average of eight lakeside gauges, tended to underestimate over-lake rainfall (Datta, 1981). This underestimate has recently been confirmed by Nicholson et al. (2000) using satellite cold-cloud data to estimate rainfall over the lake and land area. Lake rainfall is found to be a relatively constant $321 \mathrm{~mm}$ higher than rainfall over the land area which allows for an improved simulation of observed Lake Victoria levels. Conway and Hulme (1993) calculated that the $2.25 \mathrm{~m}$ increase in lake level between 1961-64 would account for roughly eight years of the excess outflows after levels peaked in 1964 and together with generally higher rainfall after 1964 than before 1961, this could account for the sustained high levels. Lake Victoria is likely to have a long response time to 
perturbations to its water balance given its vast area and wetlands around the lake perimeter and in upper tributaries such as the Kagera. Indeed, using a theoretical model of Lake Victoria and the downstream lakes and Sudd swamps, Sene (2000) obtains a period of 10-20 years for Lake Victoria levels to decline towards their initial equilibrium values following a perturbation.

The increase in rainfall subsequent to 1961 has been noted in other studies, although Rodhe and Virji (1976) found no evidence of long-term trends in annual rainfall at six rain gauges around Lake Victoria. Farmer (1981) found evidence of a step-like increase in mean ON rainfall over the Kenyan area of Lake Victoria in the early 1960s. Farmer postulated that a positive feedback, created by increased lake surface area generating increased local moisture and rainfall, could have triggered an increase in the Lake basin rainfall. Hulme et al. (in press) found a positive trend in annual rainfall over East Africa of +10 per cent per century (based on 1900-1998). Table 3 shows significant increases in mean ON rainfall over $5^{\circ} \mathrm{N}$ to $5^{\circ} \mathrm{S}$ from 1931 60 to $1961-90$ (ON 1931-90 trend is $1.2 \mathrm{~mm}$ per year). Large increases in JJAS and $\mathrm{ON}$ rainfall occurred over $5-10^{\circ} \mathrm{S}$, and annual increases over $10-15^{\circ} \mathrm{S}$. In contrast, northwards of $5^{\circ} \mathrm{N}$ the zonal average time series show substantial decreases in rainfall between both periods in nearly all seasons.

\section{DISCUSSION AND CONCLUSIONS}

\subsection{Discussion}

These results go some way towards understanding the 1961 and 1997 extreme events particularly in terms of their spatio-temporal characteristics, hydrological impacts and possible precedents. However, questions remain about their causes, frequency, and association with ENSO and the Indian Ocean DMI.

Both events were associated with a dipole-like periodic reversal of Indian Ocean SSTs that is independent of the ENSO. Webster et al. (1999) identified a total of 16 years between 1950 and 1998 in which the equatorial SST gradient (or DMI) reversed for at least a month. Saji et al. (1999) identified six extreme dipole events since 1958 in 1961, 1967, 1972, 1982, 1994 and 1997 with smaller events in 1977 and 1992. These years all coincide with wet ON seasons (Figure 2) but none have produced hydrological impacts on the scale of those that occurred in 1961 and 1997.

It is not entirely clear to what extent these Indian Ocean events have been influenced by the effects of ENSO and Pacific Ocean SSTs. 1961 was a non-El Niño year but 1997 and 1878 (the most likely historical precedent, in terms of hydrological impacts) were both strong El Niño years. 
Extreme Rainfall Events and Lake Level Changes in East Africa 86

Table 3. Seasonal and annual 30-year mean rainfall for zonal average time series. Percentage difference between 1931-60 and 1961-90 is shown. Trend is shown using correlation with time over 1931-1990, bold figures represent significant correlation at the $5 \%$ level.

\begin{tabular}{|c|c|c|c|c|c|}
\hline & & Mean 31-60 & Mean 61-90 & $\%$ diff. & Correlation with time \\
\hline \multirow[t]{4}{*}{$15-20^{\circ} \mathrm{N}$} & MAM & 5 & 3 & -44 & -0.23 \\
\hline & JJAS & 98 & 68 & -31 & -0.30 \\
\hline & $\mathrm{ON}$ & 7 & 6 & -9 & -0.07 \\
\hline & Annual & 116 & 82 & -29 & -0.34 \\
\hline \multirow[t]{4}{*}{$10-15^{\circ} \mathrm{N}$} & MAM & 56 & 28 & -50 & -0.47 \\
\hline & JJAS & 442 & 365 & -17 & -0.57 \\
\hline & $\mathrm{ON}$ & 34 & 24 & -30 & -0.45 \\
\hline & Annual & 536 & 421 & -21 & -0.71 \\
\hline \multirow[t]{4}{*}{$5-10^{\circ} \mathrm{N}$} & MAM & 283 & 254 & -10 & -0.31 \\
\hline & JJAS & 575 & 526 & -9 & -0.35 \\
\hline & ON & 118 & 126 & 7 & -0.04 \\
\hline & Annual & 1035 & 954 & -8 & -0.50 \\
\hline \multirow[t]{4}{*}{$0-5^{\circ} \mathrm{N}$} & MAM & 414 & 405 & -2 & -0.05 \\
\hline & JJAS & 403 & 392 & -3 & -0.10 \\
\hline & $\mathrm{ON}$ & 187 & 241 & 29 & 0.20 \\
\hline & Annual & 1153 & 1176 & 2 & -0.03 \\
\hline \multirow[t]{4}{*}{$0-5^{\circ} \mathrm{S}$} & MAM & 473 & 475 & 0 & -0.03 \\
\hline & JJAS & 141 & 151 & 6 & -0.03 \\
\hline & ON & 164 & 229 & 40 & 0.21 \\
\hline & Annual & 1027 & 1109 & 8 & 0.06 \\
\hline \multirow[t]{4}{*}{$5-10^{\circ} \mathrm{S}$} & MAM & 454 & 421 & -7 & -0.26 \\
\hline & JJAS & 48 & 62 & 30 & 0.00 \\
\hline & ON & 126 & 149 & 18 & 0.10 \\
\hline & Annual & 1016 & 1040 & 2 & -0.07 \\
\hline \multirow[t]{4}{*}{$10-15^{\circ} \mathrm{S}$} & MAM & 284 & 301 & 6 & 0.07 \\
\hline & JJAS & 5 & 6 & 6 & -0.06 \\
\hline & ON & 110 & 125 & 13 & 0.08 \\
\hline & Annual & 1108 & 1163 & 5 & 0.13 \\
\hline \multirow[t]{4}{*}{$15-20^{\circ} \mathrm{S}$} & MAM & 164 & 157 & -5 & -0.06 \\
\hline & JJAS & 21 & 18 & -13 & -0.05 \\
\hline & ON & 130 & 127 & -2 & -0.04 \\
\hline & Annual & 886 & 857 & -3 & -0.02 \\
\hline \multirow[t]{4}{*}{$20-25^{\circ} \mathrm{S}$} & MAM & 113 & 108 & -4 & -0.09 \\
\hline & JJAS & 24 & 28 & 16 & 0.14 \\
\hline & $\mathrm{ON}$ & 93 & 103 & 10 & 0.18 \\
\hline & Annual & 582 & 566 & -3 & -0.04 \\
\hline
\end{tabular}


ENSO has varying length lagged effects on Indian Ocean SSTs and a known influence on rainfall in the region; it accounts for around 20 per cent of variability in October-December East African rainfall. Of the 16 years between 1950 and 1998 that Webster et al. (1999) identified with SST reversals only three of these were El Niño years and none La Niña. Already there are many examples where impacts of the 1997 event in East Africa and the Indian Ocean have been, possibly wrongly, attributed directly to the ENSO, e.g. the extreme rainfall and floods (FAO/GIEW, 1998). Further work is therefore necessary to disentangle the effects of the ENSO and its influence on Indian Ocean activity and the dipole mode.

The events of 1961 and 1997 and the possibility of similar events occurring in the future raises the question of their predictability and has implications for longer-term resource management strategies in the region. Many studies have investigated the predictability of the East African short rains (e.g. Mutai et al., 1998 and Kabanda and Jury, 1999) without focusing on the 1961 or 1997 events. Saji et al. (1999) identify a SST anomaly pattern build up in the Indian Ocean as a precursor to the 1997 event and Latiff et al. (1999) discuss the possibility of prediction given the couple of months time lag between tropical Pacific anomalies and Indian Ocean anomalies. Given that Indian Ocean dipole reversals have occurred many times since 1958, but have not always been associated with extreme rainfall anomalies, the ability to forecast impacts may be limited but warrants further investigation.

There is also the possibility that climate change may alter the nature and frequency of Indian Ocean dipole events and their relationship with rainfall over East Africa. Whether such events in the past may have left a signal in environmental proxy records (either directly through prolonged lake level changes or indirectly through changes in lake sediment delivery and primary productivity) also needs to be considered when such records are interpreted (Cole et al., 2000; Verschuren et al., 2000).

The immediate hydrological impacts of such events include disruption and damage due to temporary inundation of lakeside and wetland areas and river flooding. Longer term management implications revolve around the dynamic nature of water resources over time and the need for flexible management systems that consider the inherent uncertainty in the resource base. This undermines traditional assumptions of reliable yields for planning water supply projects. For example, the dynamic nature of wetlands in response to these events is quite dramatic. In the Sudd swamps in southern Sudan the area of permanent swamp increased from 2800 $\mathrm{km}^{2}$ to $16600 \mathrm{~km}^{2}$ and the area of seasonal swamp increased from $11200 \mathrm{~km}^{2}$ to $14000 \mathrm{~km}^{2}$ after the early 1960s (Sutcliffe and Parks, 1987). Fluctuating lake levels also present management challenges and opportunities for fishing and lakeside activities (Sarch and Allison, in press). Further study of the impacts and response strategies associated with these events is necessary to provide an indication of the region's vulnerability and adaptive capacity in relation to present day climate variability and also future climate change. 


\subsection{Conclusions}

The hydrometeorological events of 1961 and 1997 show similar spatial and temporal characteristics insofar as they are directly comparable given the limited number of observations for 1997-98. Both events occurred mainly during ON and primarily affected the area between $10^{\circ} \mathrm{N}$ and $10^{\circ} \mathrm{S}$ and from at least $25^{\circ} \mathrm{E}$ to the Indian Ocean. The events are primarily located over regions where $\mathrm{ON}$ rainfall forms part of the normal rainfall season. However, some areas, north of $10^{\circ} \mathrm{N}$, recorded heavy rainfall during ON 1997, months that are normally relatively dry.

The spatio-temporal characteristics of the 1961 and 1997 events are quite exceptional in terms of magnitude and extent during the $20^{\text {th }}$ century. Zonal average $\left(5^{\circ}\right)$ rainfall series for the $20^{\text {th }}$ century highlight other years with very wet $\mathrm{ON}$ seasons spread over large regions but none as extreme in magnitude nor area as 1961 and 1997.

Riverflow records dating from around 1900 for East, Central and the Horn of Africa show no other events similar to the wide-ranging and extreme floods in 1961, continuing into 1962. The series show other common features (except for the Zambezi), such as high floods in 1916-18 in the Nile basin, particularly the Equatorial Lakes stretch of the White Nile, but they were shorter-lived and smaller in extent than the floods in 1961-62. The 1961 event affected riverflows as far north as the Sobat (up to $10^{\circ} \mathrm{N}$ ) but it is not clear whether high riverflows further north in the Blue Nile and Atbara during 1961 were connected with the event as they occurred earlier, during June-August. The event spread west over the Congo basin and as far south as Lake Malawi, but not southwest over the Zambezi headwaters.

Over the four years 1961-64 the cumulative excess river flow (above the 1961-90 mean) in the White Nile upstream of the Sudd (at Mongalla), Blue Nile, Atbara, Congo, Tana and Zambezi rivers was $11,324 \mathrm{~m}^{3} \mathrm{~s}^{-1}\left(357 \mathrm{~km}^{3} / \mathrm{yr}\right.$. This amounts to roughly four times the mean annual flow of the Nile and almost one third of the Congo.

There is not enough data for 1997 to fully assess the extent of this event in terms of impacts on riverflows and the possibility of prolonged impacts on lake levels. However, by 1998 the effects upon Lake Victoria and other East African lakes levels had been similar in magnitude to those of 1961-62, and very high flows were recorded in the Congo basin, along with widespread flooding and crop damage in the region, as in 1961 .

The closest historical precedent in terms of hydrological effects appears to be 1878 , which was a year of record floods on the Blue Nile, and very high Lake Victoria levels. From documentary evidence Nicholson (1999) notes that 1878 was a year of very heavy rains which opened Lake Tanganyika's outlet to the Congo system via the Lukuga leading to flooding downstream.

Many of the rivers had record flows in 1961 followed by high (sometimes higher) flows in 1962. Lake Victoria levels did not peak until 1964, remained above their pre-1961 level until 1997 and remain high. The persistence of high Lake Victoria levels is most likely related to the combined effects of large catchment size 
and potential for storage, very high rainfall in 1963 and, between $5^{\circ} \mathrm{N}$ and $5^{\circ} \mathrm{S}$, a significant increase in ON rainfall from 1931-60 to 1961-90 of about 35 per cent.

\section{REFERENCES}

Birkett, C.M., Murtugudde, R. and Allan, J.A. (1999) Indian Ocean climate event brings floods to East Africa's lakes and Sudd Marsh. Geophys. Res. Lett. 26, 1031-1034.

Chambers, D.P., Tapley, B.D. and Stewart, R.H. (1999) Anomalous warming in the Indian Ocean coincident with El Niño. J. Geophys. Res. 104, 3035-3047.

Charles, C.D., Hunter, D.E. and Fairbanks, R.G. (1997) Interaction Between the ENSO and the Asian Monsoon in a Coral Record of Tropical Climate. Science, 277, 925-928.

Cole, J.E., Dunbar, R.B., McClanahan, T.R. and Muthiga, N.A. (2000) Tropical pacific forcing of decadal SST variability in the Western Indian Ocean over the past two centuries. Science, 287, 617 619.

Conway, D. (1997) A spatial and temporal analysis of two extreme rainfall episodes in East Africa: 1916-1917 and 1961-1964. Fifth Int. Conf. on Southern Hemisphere Meteorology and Oceanography, Pretoria 1997. AMS Pre-print volume, pp. 158-159.

Conway, D. (2000) The climate and hydrology of the Upper Blue Nile, Ethiopia. Geog. J. 166, 49-62.

Conway, D. and Hulme, M. (1993) Recent fluctuations in precipitation and runoff over the Nile subbasins and their impact on Main Nile discharge. Climatic Change 25, 127-151.

Datta, R.R. (1981) Certain Aspects of Monsoonal Precipitation Dynamics over Lake Victoria, in Sir James Lighthill and R.P. Pearce (eds.), Monsoon Dynamics. Cambridge University Press, Cambridge, pp. 333-349.

Dixon, A. (2000) Indigenous hydrological knowledge and the management of wetlands in Illubabor, Ethiopia. Unpublished Ph.D. thesis, University of Huddersfield.

FAO/GIEW (1998) Heavy rains attributed to El Niño cause extensive crop damage in parts of Eastern Africa. www.fao.org/WAICENT/faoinf...english/alertes/1998/sreaf981.htm

Farmer, G. (1981) Regionalisation and Study of An Alleged Change in the Regional Climatology of East Africa. Unpublished Ph.D. Thesis, University of Sheffield, U.K.

Flohn, H. (1987) East African Rains of 1961/62 and the Abrupt Change of the White Nile Discharge. Palaeoecology of Africa 18, 3-18.

Flohn, H. and Burkhardt, T.H. (1985) Nile Runoff at Aswan and Lake Victoria: A Case of Discontinuous Climate Time Series. Zeitschr. Gletscherkde. Glaziolgeol. 21, 125-130.

Grötzner, A., Latif, M. and Dommenget, D. (1999): Atmospheric response to sea surface temperature anomalies during El Niño 1997/1998. Q. J. Roy. Met. Soc., 126, 2175-2198.

Grove, A.T. (1996) African river discharges and lake levels in the Twentieth Century, in T. C Johnson and E. O. Odada (eds.), The Limnology, Climatology and Paleoclimatology of the East African Lakes, Gordon and Breach, The Netherlands, pp. 95-100.

Hulme, M. (1994) Validation of large-scale precipitation fields in General Circulation Models, in M. Desbois and F. Desalmand (eds.), Global Precipitation and Climate Change, NATO ASI Series, Vol. 126, Springer-Verlag, Berlin, Heidelberg, pp. 387-405.

Hulme, M., Doherty, R., Ngara, T., New, M. and Lister, D. (in press) African Climate Change: 19002100. Clim. Res., in press.

Hurst, H.E. and Phillips, P. (1933) The Nile Basin, Volume IV. Ten-day Mean and Monthly Mean Discharges of the Nile and its Tributaries. Ministry of Public Works, Physical Department, Cairo.

IRD (1999) Observatoire hydrologique regional de l'Afrique de l'Ouest et Centrale. Accessed online at http://ohraoc.orstom.bf/HTML/ETUDES/HYDRO/BRAZZA.HTM. Accessed on 19/05/99.

Janowiak, JE and Xie, P. (1999) CAMS-OPI: A global satellite-rain gauge merged product for real-time precipitation monitoring applications. J. Climate 12, 3335-3342.

Jones, P.D. and Conway, D. (1997) Precipitation in the British Isles: an analysis of area-average data updated to 1995. Int. J. Climatol. 17, 427-438.

Kabanda, T.A. and Jury, M.R. (1999) Inter-annual variability of short rains over northern Tanzania. Clim. Res. 13, 231-241. 
Kite, G.W. (1981) Recent Changes in Level of Lake Victoria. Hydrol. Sci. Bull. 26, 233-243.

Lamb, H.H. (1966) Climate in the 1960s. Geog. J. 132, 183-212.

Laraque A., Maziezoula, B., Orange, D., Olivry, J. C. (1998) Origine des variations de débits du Congo à Brazzaville durant le XXième siècle, in E. Servat, D. Hughes, Jean-Marie Fritsch and M. Hulme (eds.), Water Resources Variability in Africa during the XXth Century, IAHS Publ. no. 252, pp. 171-180.

Latif M., Dommenget D., Dima M., Grotzner A. (1999) The role of Indian Ocean sea surface temperature in forcing east African rainfall anomalies during December-January 1997/98. J. Climate 12, $3497-$ 3504.

Lyons, H.G. (1906) The Physiography of the River Nile and its Basin. Royal Met. Soc. Cairo.

Mörth, H.T. (1967) Investigations into the Meteorological Aspects of the Variations in the Level of Lake Victoria. East African Met. Dept. Memoirs 4, 1-22.

Murtugudde, R., McCreary Jr., J.P. and Busalacchi, A.J. (2000) Oceanic processes associated with anomalous events in the Indian Ocean with relevance to 1997-1998. J. Geophys. Res. 105, 32953306.

Mutai, C.C., Ward, M.N. and Colman, A.W. (1998) Towards the prediction of the East Africa short rains based on sea-surface temperature-atmosphere coupling. Int. J. Climatol. 18, 975-997.

Nicholson, S.E. (1997a) Historical fluctuations of Lake Victoria and other lakes in the northern Rift Valley of East Africa, in Lehman, J.T. (ed.), Environmental change and response in East African lakes. Kluwer, Dordrecht, pp. 7-35.

Nicholson, S.E. (1997b) Fluctuations of Rift Valley lakes Malawi and Chilwa during historical times: a synthesis of geological, archaeological and historical information, in Lehman, J.T. (ed.), Environmental change and response in East African lakes. Kluwer, Dordrecht, pp. 207-231.

Nicholson, S.E. (1999) Historical and modern fluctuations of lakes Tanganyika and Rukwa and their relationship to rainfall variability. Climatic Change 41, 53-71.

Nicholson, S.E., Yin, X. and Ba, M.B. (2000). On the feasibility of using a lake water balance model to infer rainfall: an example from Lake Victoria. Hyd. Sci. J. 45, 75-95.

Odingo, R.S. (1962) The abnormal and unseasonal rains in East Africa. The Geographical Review 52, 440-442.

Piper, B.S., Plinston, D.T. and Sutcliffe, J.V. (1986) The Water Balance of Lake Victoria. Hydrol. Sci. J. 31, 25-37.

Reason, C.J.C., Allan, R.J., Lindesay, J.A. and Ansell, T.J. (2000) ENSO and climatic signals across the Indian Ocean Basin in the global context: Part I, interannual composite patterns. Int. J. Climatol. 20, 1285-1327.

Reverdin, G., Cadet, D.L. and Gutzler, D. (1986) Interannual displacements of convection and surface circulation over the equatorial Indian Ocean. Quart. J. R. Met. Soc. 112, 43-67.

Rodhe, H. and Virji, H. (1976) Trends and Periodicities in East African Rainfall Data. Monthly Weather Review 104, 307-315.

Saji, N.H., Boswami, B.N., Vinayachanran, P.N. and Yamagata, T. (1999) A Dipole Mode in the Tropical Indian Ocean. Nature 401, 360-363.

Sarch, M-T. and Allison, E. (in press) Fluctuating fisheries in Africa's inland waters: well adapted livelihoods, maladapted management. Proceedings of International Institute of Fisheries Economics and Trade (IIFET), 10th International Conference. Eugene, Oregon, July 2000.

Sene, K.J. (2000). Theoretical estimates for the influence of Lake Victoria on flows in the Upper White Nile. Hyd. Sci. J. 45, 125-145.

Sutcliffe, J.V. and Parks, Y.P. (1987) Hydrological Modelling of the Sudd and Jonglei Canal. Hydrol. Sci. J. 32, 143-159.

Sutcliffe, J.V. and Parks, Y.P. (1999) The Hydrology of the Nile. IAHS Special Publication No. 5. IAHS Press, Wallingford, Oxfordshire.

UNESCO (1995) Discharge of selected rivers of Africa. UNESCO Studies in hydrology No 52.

Venzke, S., Latif, M. and Villwock, A. (in press): The coupled GCM ECHO-2. Part II: Indian Ocean response to ENSO. J. Climate, in press

Verschuren D. Laird, K.R. and Cumming, B.F. (2000) Rainfall and drought in equatorial east Africa during the last 1,100 years. Nature 403, 410-413.

Walsh, R.P.D., Davies, H.R.J. and Musa, S.B. (1994) Flood frequency and impacts at Khartoum since the early nineteenth century. Geog. J. 160, 266-279. 
Webster, P.J., Moore, A.M., Loschnigg, J.P. and Lebden, R.R. (1999) Coupled Ocean-Atmosphere Dynamics in the Indian Ocean During 1997-98. Nature 401, 356-360.

Xie, P.P. and Arkin, P.A. (1998) Global monthly precipitation estimates from satellite-observed outgoing longwave radiation. Journal of Climate 11, 137-164. 